\title{
PTBP3 Gene
}

National Cancer Institute

\section{Source}

National Cancer Institute. PTBP3 Gene. NCI Thesaurus. Code C114436.

This gene plays a role in RNA splicing, cellular differentiation and erythropoiesis. 